\title{
Editorial
}

\section{Treatment Option for Aged, Multiparous Women With a Chronic Anal Fissure}

\author{
Yong Hee Hwang \\ Department of Surgery, Sahmyook Medical Center, Seoul, Korea
}

\section{See Article on Page 132-134}

Chronic anal fissures are a common disease and show a high recurrence rate even though after various treatment modalities have been applied. The lateral internal sphincterectomy is the most successful treatment modality, but is difficult to apply to aged patients or multiparous women due to postoperative fecal incontinence [1, 2]. In these cases, a stepwise approach of Diltiazem and Botox injection with an anal fissurectomy is a good alternative for reducing postoperative fecal incontinence [3]. However, the high treatment cost and the lengthy treatment time are two obstacles that need to be resolved, so pretreatment counseling and strict indications for the selection of such a treatment modality are essential.

\section{REFERENCES}

1. Corby H, Donnelly VS, O'Herlihy C, O'Connell PR. Anal canal pressures are low in women with postpartum anal fissure. $\mathrm{Br}$ J Surg 1997;84:86-8.

2. Frudinger A, Halligan S, Bartram CI, Price AB, Kamm MA, Winter R. Female anal sphincter: age-related differences in asymptomatic volunteers with high-frequency endoanal US. Radiology 2002;224:417-23.

3. Farouk R. Sphincter-preserving therapy for treating a chronic anal fissure: long-term outcomes. Ann Coloproctol 2014;30:132-4.

Correspondence to: Yong Hee Hwang, M.D.

Department of Sugery, Sahmyook Medical Center, 82 Mangu-ro,

Dongdaemun-gu, Seoul 130-711, Korea

Tel: +82-2-2210-3563, Fax: +82-2-2212-2673

E-mail: hwangyon@hotmail.com

(C) 2014 The Korean Society of Coloproctology

This is an open-access article distributed under the terms of the Creative Commons Attribution NonCommercial License (http://creativecommons.org/licenses/by-nc/3.0) which permits unrestricted non-

commercial use, distribution, and reproduction in any medium, provided the original work is properly cited. 